Article

\title{
Biomimetic Synthesis of Resveratrol Trimers Catalyzed by Horseradish Peroxidase
}

\author{
Jian-Qiao Zhang ${ }^{1}$, Gan-Peng Li ${ }^{2}$, Yu-Long Kang ${ }^{1}$, Bin-Hao Teng ${ }^{1}$ and Chun-Suo Yao ${ }^{1, *}$ \\ 1 State Key Laboratory of Bioactive Substance and Function of Natural Medicines, Institute of Materia Medica, \\ Chinese Academy of Medical Sciences \& Peking Union Medical College, Beijing 100050, China; \\ jqzhang@imm.ac.cn (J.-Q.Z.); kangyulongzyy@imm.ac.cn (Y.-L.K.); tengbh@imm.ac.cn (B.-H.T.) \\ 2 Key Laboratory of Chemistry in Ethnic Medicinal Resources, State Ethnic Affairs Commission \& Ministry \\ of Education, Yunnan Minzu University, Kunming 650500, China; ganpeng_li@sina.com \\ * Correspondence: yaocs@imm.ac.cn; Tel.: +86-10-6021-2110; Fax: +86-10-6301-7757
}

Academic Editor: Derek J. McPhee

Received: 31 March 2017; Accepted: 11 May 2017; Published: 17 May 2017

\begin{abstract}
Biotransformation of trans-resveratrol and synthetic $( \pm)-\varepsilon$-viniferin in aqueous acetone using horseradish peroxidase and hydrogen peroxide as oxidants resulted in the isolation of two new resveratrol trimers ( 3 and 4 ), one new resveratrol derivative (5) with a dihydrobenzofuran skeleton, together with two known stilbene trimers (6 and 7), and six known stilbene dimers (8-13). Their structures and relative configurations were identified through spectral analysis and possible formation mechanisms were also discussed. Among these oligomers, trimers 6 and 7 were obtained for the first time through direct transformation from resveratrol. Results indicated that this reaction is suitable for the preparation of resveratrol oligomers with a complex structure.
\end{abstract}

Keywords: horseradish peroxidase; $\varepsilon$-viniferin; resveratrol trimer; biotransformation; radical reaction

\section{Introduction}

Stilbenes are a class of plant polyphenols that can be divided into two categories, namely, monomeric and oligomeric stilbenes. Resveratrol oligomers possess novel structures and exhibit various biological activities, such as anticarcinogenesis, anti-inflammation, and tyrosinase activity inhibition. These oligomers can be used to treat cancer, AIDS, bacterial infections, and other diseases. Some oligostilbenes exhibit more potent bioactivities than their monomers do [1-3].

Various resveratrol oligomers exist in nature, especially in grapevine. However, the structures of minor stilbene oligomers have yet to be elucidated because sufficient amounts of these minor components are difficult to isolate for subsequent structural characterization. In recent years, some researchers focused their attention on the synthesis of these oligomers and total synthetic routes of numerous resveratrol oligomers, including dimers, trimers, and tetramers, have been reported in literature [4-10], but long reaction steps render these approaches unsuitable for specific preparations of the complex oligomers. Therefore, biomimetic synthesis is still a concise and practical alternative for the preparation of oligostilbenes with intricate structures. The natural biotransformation of stilbene oligomers in nature can be simulated in vitro by transformation with biological enzymes, unorganized fermentation, metal oxidants, light, acids and alkali [2,11]. In combination with diverse separation methods, transformation can induce the accumulation of large amounts of minor compounds. Using this approach, a number of known natural stilbene oligomers and new stilbene oligomers have been obtained, and their structures have also been identified successfully [11]. The oxidative coupling of resveratrol, including its analogs, has been examined under different conditions since $\varepsilon$-viniferin was first isolated in 1977 by Langcake and Pryce [12]. Nevertheless, the in vitro biocatalyzed oxidation of stilbenes has rarely been explored, and studies on biocatalyzed 
enzymes have focused on horseradish peroxidase (HRP) and laccase $[13,14]$, which indicated that dimers, such as dihydrobenzofuran-like dimers, are the main products of reactions mediated by these enzymes. As reported in the literature [12,15], $\varepsilon$-viniferin, which would be synthesized enzymatically in plant tissues, seems to be a biogenetically important precursor of many oligostilbenes in plants, such as davidiol A, davidiol B, hopeaphenol, ampelopsin E, and so on. So, biotransformation of $\varepsilon$-viniferin is a promising way to prepare these oligomers. Wilkens et al. [16] reported the transformation of resveratrol and $(-)-\varepsilon$-viniferin catalyzed by HRP produces different stilbene oligomers, including dimers, trimers, tetramers, and polymeric products. In addition to two trimeric stilbenes obtained in a pure form, other oligomers only have been detected through HPLC-PDA or HPLC-ESI-MS/MS. Many resveratrol trimers and tetramers can be possibly obtained by further investigating this reaction. As an extension of the preliminary work, this study demonstrated the biotransformation of trans-resveratrol (1) and synthetic ( \pm )- $\varepsilon$-viniferin (2) in aqueous acetone with HRP and hydrogen peroxide as oxidants. Thus, two new resveratrol trimers ( 3 and 4$)$, one new resveratrol derivative (5) with a dihydrobenzofuran skeleton, together with two known natural stilbene trimers (6 and 7), and six known natural stilbene dimers (8-13) were isolated and structurally identified (Figure 1). Among these substances, trimers $\mathbf{6}$ and 7 were obtained for the first time through direct transformation from resveratrol. Moreover, their potential formation mechanisms were also discussed.

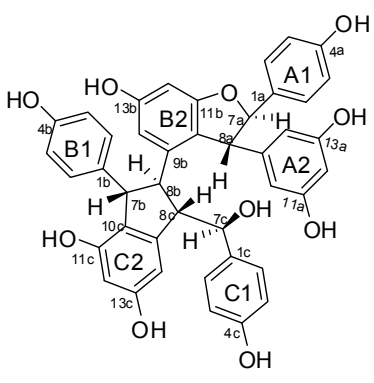

3

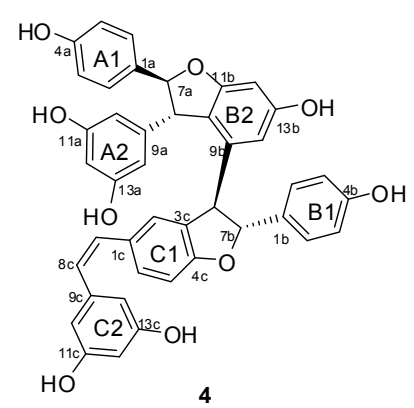

4

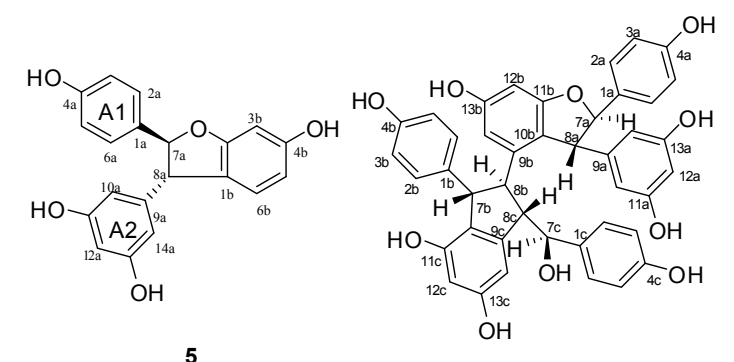

Davidiol B (6)

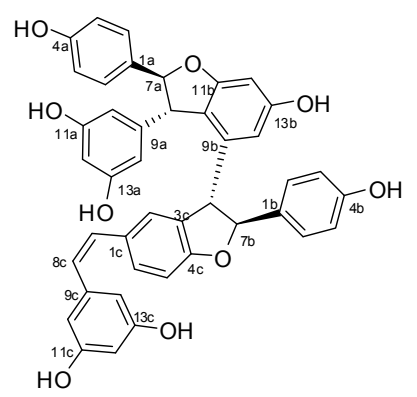

$r e l-(7 \mathrm{a} S, 8 \mathrm{a} S, 7 \mathrm{~b} S, 8 \mathrm{~b} S)$-cis-Diptoindonesin B (7)

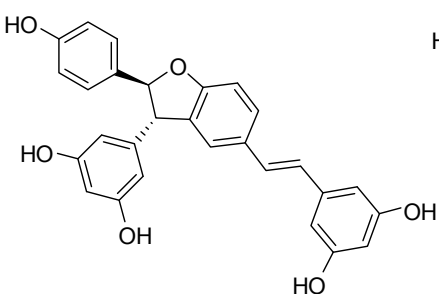

Resveratrol-trans-dehydrodimer (8)

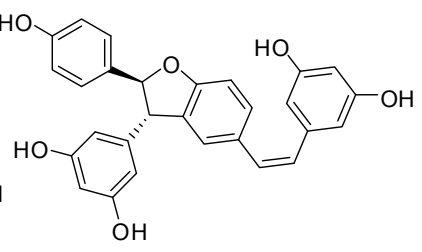

Resveratrol-cis-dehydrodimer (9)

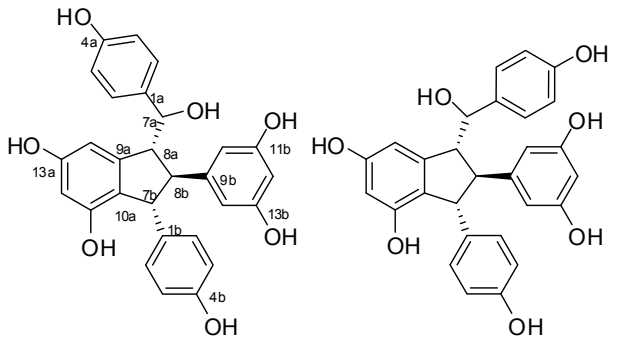

Leachianol G (10)

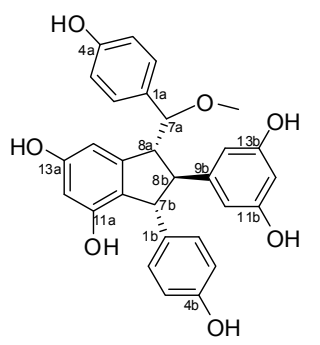

Parthenostilbenin B (12)

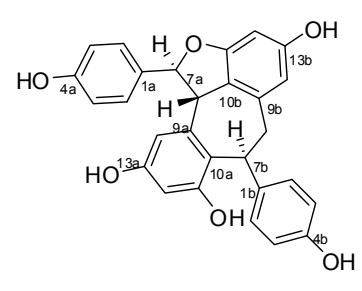

Ampelopsin B (13)

Figure 1. Structures of compounds 3-13. 


\section{Results and Discussion}

\subsection{Synthesis of $\mathbf{2}$ with Resveratrol as a Starting Material and HRP and Hydrogen Peroxide-Catalyzed} Biotransformation of $\mathbf{1}$ and $\mathbf{2}$

In this study, semisynthetic $( \pm)$ - $\varepsilon$-viniferin (2) under the procedure shown in Figure 2 was used as the starting material for biotransformation. According to the method reported in our previous paper [17], trans-resveratrol was subjected to an oxidative coupling reaction in aqueous methanol using $\mathrm{FeCl}_{3} \cdot 6 \mathrm{H}_{2} \mathrm{O}$ as an oxidant, and this procedure was performed in combination with column chromatography on silica gel. Thus, 2 with $13.5 \%$ yield was produced.
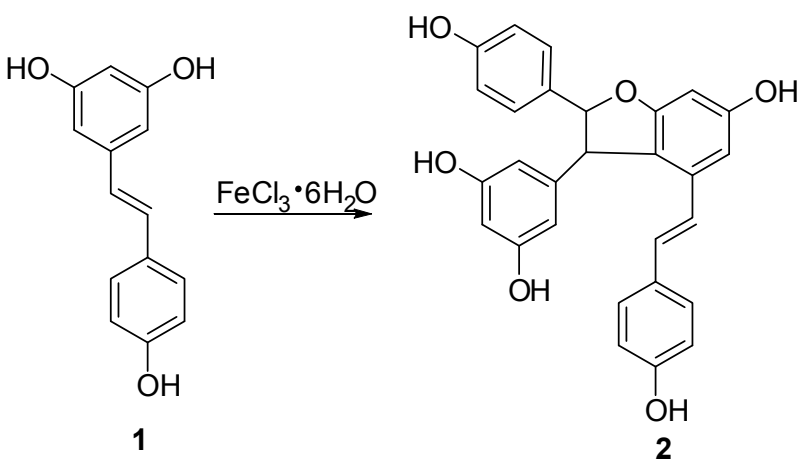

Figure 2. Semi-synthetic route of compound 2.

Successively, biotransformation of $\mathbf{1}$ and $\mathbf{2}$ in aqueous acetone catalyzed by horseradish peroxidase and hydrogen peroxide generated a major product peak 8 and a complicated mixture (Figure S30 in Supplementary Materials), which resulted in the isolation and identification of four resveratrol trimers $(3,4,6$, and 7 , where 3 and 4 are new ones), one new resveratrol derivative 5 , and six known dimers (8-13) (Figure 1). Their structures and stereochemistry were elucidated by analyzing spectroscopic data.

\subsection{Structure Elucidation of Biotransformation Products}

Compound 3 was obtained as a brown amorphous powder. The negative ion peak at $m / z 697.2076$ $[\mathrm{M}-\mathrm{H}]^{-}$(cacld. for $\mathrm{C}_{42} \mathrm{H}_{33} \mathrm{O}_{10}, 697.2079$ ) in its HR-ESI-MS (Figure S7) corresponded to the molecular formula of $\mathrm{C}_{42} \mathrm{H}_{34} \mathrm{O}_{10}$ and indicated that 3 could be a resveratrol trimer. The IR spectrum (Figure S9) revealed the presence of hydroxyls $\left(\nu_{\max }=3395\right.$ and $\left.3187 \mathrm{~cm}^{-1}\right)$ and aromatic rings $\left(\nu_{\max }=1600\right.$, 1513, and $\left.1469 \mathrm{~cm}^{-1}\right)$. Absorption bands were also observed at $\lambda_{\max }(\log \varepsilon) 203$ (5.14), 231 (4.66), and 283 (3.92) $\mathrm{nm}$ in the UV spectrum (Figure S8). The ${ }^{1} \mathrm{H}-\mathrm{NMR}$ spectrum (Figure S1, Table 1) showed three sets of $\mathrm{A}_{2} \mathrm{~B}_{2}$ systems for rings $\mathrm{A} 1, \mathrm{~B} 1$, and $\mathrm{C} 1$ at $\delta_{\mathrm{H}}$ of $6.83(2 \mathrm{H}, \mathrm{d}, J=8.4 \mathrm{~Hz}, \mathrm{H}-3(5) \mathrm{a}), 7.24(2 \mathrm{H}, \mathrm{d}$, $J=8.4 \mathrm{~Hz}, \mathrm{H}-2(6) \mathrm{a}), 6.54(2 \mathrm{H}, \mathrm{d}, J=8.4 \mathrm{~Hz}, \mathrm{H}-3(5) \mathrm{b}), 6.34(2 \mathrm{H}, \mathrm{d}, J=8.4 \mathrm{~Hz}, \mathrm{H}-2(6) \mathrm{b}) ; 6.68$ (2H, d, $J=8.4 \mathrm{~Hz}, \mathrm{H}-3(5) \mathrm{c})$, and $6.85(2 \mathrm{H}, \mathrm{d}, J=8.4 \mathrm{~Hz}, \mathrm{H}-2(6) \mathrm{c})$; one set of $\mathrm{AB}_{2}$ system for ring $\mathrm{A} 2$ at $\delta_{\mathrm{H}}$ of $6.36(1 \mathrm{H}, \mathrm{t}, J=2.4 \mathrm{~Hz}, \mathrm{H}-12 \mathrm{a})$ and $6.20(2 \mathrm{H}, \mathrm{d}, J=2.4 \mathrm{~Hz}, \mathrm{H}-10(14) \mathrm{a})$; two sets of meta-coupled aromatic protons for rings B2 and C2 at $\delta_{\mathrm{H}}$ of $5.98(1 \mathrm{H}, \mathrm{d}, J=2.4 \mathrm{~Hz}, \mathrm{H}-14 \mathrm{~b})$ and $6.19(1 \mathrm{H}, \mathrm{d}, J=2.4 \mathrm{~Hz}, \mathrm{H}-12 \mathrm{~b})$, and $\delta_{\mathrm{H}} 5.17(1 \mathrm{H}, \mathrm{d}, J=1.8 \mathrm{~Hz}, \mathrm{H}-14 \mathrm{c})$ and $6.24(1 \mathrm{H}, \mathrm{d}, J=1.8 \mathrm{~Hz}, \mathrm{H}-12 \mathrm{c})$. The ${ }^{1} \mathrm{H}-\mathrm{NMR}$ spectrum also displayed the presence of two mutually coupled benzyl methine protons at $\delta_{\mathrm{H}}$ of $5.33(1 \mathrm{H}, \mathrm{d}$, $J=3.0 \mathrm{~Hz}, \mathrm{H}-7 \mathrm{a})$ and $4.83(1 \mathrm{H}, \mathrm{d}, J=3.0 \mathrm{~Hz}, \mathrm{H}-8 \mathrm{a})$ and a sequence of successively coupled benzyl methine protons at $\delta_{\mathrm{H}}$ of $4.30(1 \mathrm{H}, \mathrm{brs}, \mathrm{H}-7 \mathrm{~b}), 3.76(1 \mathrm{H}, \mathrm{brs}, \mathrm{H}-8 \mathrm{~b}), 4.02(1 \mathrm{H}, \mathrm{dd}, J=4.2,3.0 \mathrm{~Hz}, \mathrm{H}-7 \mathrm{c})$, and $2.96(1 \mathrm{H}, \mathrm{m}, \mathrm{H}-8 \mathrm{c})$. Moreover, the HSQC spectrum (Figure S4) supplied the complete assignment of all protonated carbon, as shown in Table 1. The ${ }^{13} \mathrm{C}-\mathrm{NMR}$ spectrum (Figure S2, Table 1) of 3 revealed the presence of six aliphatic carbons at $\delta_{C}$ of 52.64,54.45,65.07, 77.10,54.73, and 93.78 ppm and 36 aromatic carbons. The aliphatic carbon at $\delta_{C}$ of $77.10 \mathrm{ppm}$ was due to an alcohol carbon. The carbon signals at $\delta_{\mathrm{C}}$ of 54.73 and 93.78 ppm and proton signals at $\delta_{\mathrm{H}}$ of 5.33 and 4.83 suggested the presence of dihydroxybenzofuran ring. The three remaining aliphatic protons and three carbon atoms indicated 
the presence of an indane ring. This group of evidence demonstrated that 3 possessed a skeleton similar to that of davidiol B [18,19]. In addition, compared with those of davidiol B, the downfield shifts of H-2(6)a, H-7a, H-8a, H-10(14)a, H-8b, and H-2(6)c in $3\left(\Delta \delta_{\mathrm{H}}+0.24,+0.28,+1.72,+0.29,+0.95\right.$, and $+0.50 \mathrm{ppm}$ ) caused by the anisotropic effect of the aromatic ring suggested that 3 could be a 7c-empimer of davidiol B [20]. In the HMBC spectrum (Figure S5 and Figure 3a) of 3, the correlations of H-2c, H-6c, H-14c, and C-7c, which were attached to the hydroxyl group, showed that C-7c was excluded from the additional ring, and ring $\mathrm{C} 1$ was attached at $\mathrm{C}-7 \mathrm{c}$. The correlations between $\mathrm{H}-7 \mathrm{~b}$, $\mathrm{H}-8 \mathrm{~b}, \mathrm{H}-5 \mathrm{~b}$, and $\mathrm{C}-1 \mathrm{~b}$ verified that ring $\mathrm{B} 1$ was connected at $\mathrm{C}-7 \mathrm{~b}$. Moreover, the correlations between $\mathrm{H}-7 \mathrm{a}$ and C-10(14)a and H-8a and C-2(6)a substantiated that ring A1 was linked at C-7a, and ring A2 was linked at C-8a. Comparison of the spectral data with those of davidiol B and the analysis of DEPT, HMBC, and HSQC (Figures S3 S5) correlations determined the planar structure of 3 (Figure 1).

Table 1. ${ }^{1} \mathrm{H}$ - and ${ }^{13} \mathrm{C}-\mathrm{NMR}$ spectroscopic data of compounds $3-5$ *

\begin{tabular}{|c|c|c|c|c|c|c|}
\hline No. & & 3 & & 4 & 5 & \\
\hline $1 \mathrm{a}$ & $134.69 \mathrm{~s}$ & & $133.85 \mathrm{~s}$ & & $131.98 \mathrm{~s}$ & \\
\hline $2(6) a$ & $128.25 \mathrm{~d}$ & $7.24(\mathrm{~d}, 8.4)$ & $128.80 \mathrm{~d}$ & $7.00(\mathrm{~d}, 9.0)$ & $127.59 \mathrm{~d}$ & $7.20(\mathrm{~d}, 8.5)$ \\
\hline $3(5) a$ & $116.04 \mathrm{~d}$ & $6.83(\mathrm{~d}, 8.4)$ & $116.36 \mathrm{~d}$ & $6.80(\mathrm{~d}, 9.0)$ & $115.14 d$ & $6.82(\mathrm{~d}, 8.5)$ \\
\hline $4 a$ & 158.11s & & $158.58 \mathrm{~s}$ & & $157.36 \mathrm{~s}$ & \\
\hline $7 a$ & $93.78 d$ & $5.33(\mathrm{~d}, 3.0)$ & $95.00 \mathrm{~d}$ & $5.22(\mathrm{~d}, 6.1)$ & $92.53 d$ & $5.34(\mathrm{~d}, 8.3)$ \\
\hline $8 \mathrm{a}$ & $54.73 d$ & $4.83(\mathrm{~d}, 3.0)$ & $57.8 \mathrm{~d}$ & $3.85(\mathrm{~d}, 6.1)$ & $57.66 \mathrm{~d}$ & $4.36(\mathrm{~d}, 8.3)$ \\
\hline $9 a$ & $149.28 \mathrm{~s}$ & & $147.28 \mathrm{~s}$ & & $144.29 \mathrm{~s}$ & \\
\hline $10 a$ & $107.13 d$ & $6.20(\mathrm{~d}, 2.4)$ & $107.27 d$ & $5.94(\mathrm{~d}, 2.4)$ & $106.51 d$ & $6.16(\mathrm{~d}, 2.1)$ \\
\hline $11 \mathrm{a}$ & $159.93 s$ & & $159.56 \mathrm{~s}$ & & $158.79 \mathrm{~s}$ & \\
\hline $12 \mathrm{a}$ & $101.82 \mathrm{~d}$ & $6.36(t, 2.4)$ & $101.90 \mathrm{~d}$ & $6.09(t, 2.4)$ & $101.34 d$ & $6.25(\mathrm{t}, 2.1)$ \\
\hline $13 a$ & $159.93 \mathrm{~s}$ & & $159.56 \mathrm{~s}$ & & 158.79 & \\
\hline $14 \mathrm{a}$ & $107.13 d$ & $6.20(\mathrm{~d}, 2.4)$ & $107.27 d$ & $5.94(\mathrm{~d}, 2.4)$ & $106.51 d$ & $6.16(\mathrm{~d}, 2.1)$ \\
\hline $1 b$ & 137.41s & & 131.87s & & $153.02 \mathrm{~s}$ & \\
\hline $2 b$ & $129.35 d$ & $6.34(\mathrm{~d}, 8.4)$ & $128.53 \mathrm{~d}$ & $7.14(\mathrm{~d}, 8.4)$ & $131.30 \mathrm{~s}$ & \\
\hline $3 b$ & $115.48 d$ & $6.54(\mathrm{~d}, 8.4)$ & $116.30 d$ & $6.75(\mathrm{~d}, 8.4)$ & $112.10 \mathrm{~d}$ & $6.47(\mathrm{~d}, 2.2)$ \\
\hline $4 b$ & $155.85 \mathrm{~s}$ & & $158.69 \mathrm{~s}$ & & $151.57 \mathrm{~s}$ & \\
\hline $5 b$ & $115.48 d$ & $6.54(\mathrm{~d}, 8.4)$ & $116.30 \mathrm{~d}$ & $6.75(\mathrm{~d}, 8.4)$ & $109.08 \mathrm{~d}$ & 6.67 (brs) \\
\hline $6 b$ & $129.35 d$ & $6.34(\mathrm{~d}, 8.4)$ & $128.53 \mathrm{~d}$ & $7.14(\mathrm{~d}, 8.4)$ & $114.69 \mathrm{~d}$ & 6.67 (brs) \\
\hline $7 \mathrm{~b}$ & $52.64 d$ & $4.30(\mathrm{~s}, 1 \mathrm{H})$ & $94.86 \mathrm{dd}$ & $5.30(\mathrm{~d}, 8.4)$ & & \\
\hline $8 b$ & $54.45 \mathrm{~d}$ & $3.76(\mathrm{~s}, 1 \mathrm{H})$ & $58.78 \mathrm{~d}$ & $4.30(\mathrm{~d}, 8.4)$ & & \\
\hline $9 b$ & $147.43 \mathrm{~s}$ & & $145.04 \mathrm{~s}$ & & & \\
\hline $10 \mathrm{~b}$ & $119.71 \mathrm{~s}$ & & $120.40 \mathrm{~s}$ & & & \\
\hline $11 b$ & $161.56 \mathrm{~s}$ & & $162.74 \mathrm{~s}$ & & & \\
\hline $12 b$ & $95.45 \mathrm{~d}$ & $6.19(\mathrm{~d}, 2.4)$ & $96.83 d$ & $6.23(\mathrm{~d}, 2.4)$ & & \\
\hline $13 b$ & $159.93 s$ & & $159.48 \mathrm{~s}$ & & & \\
\hline $14 \mathrm{~b}$ & $104.82 d$ & $5.98(\mathrm{~d}, 2.4)$ & $109.40 \mathrm{~d}$ & $6.25(\mathrm{~d}, 2.4)$ & & \\
\hline $1 c$ & $136.42 \mathrm{~s}$ & & $131.51 \mathrm{~s}$ & & & \\
\hline $2 c$ & $129.22 d$ & $6.85(\mathrm{~d}, 8.4)$ & $127.36 \mathrm{~d}$ & $6.76(\mathrm{~d}, 2.4)$ & & \\
\hline $3 c$ & $115.33 d$ & $6.68(\mathrm{~d}, 8.4)$ & $132.74 \mathrm{~s}$ & & & \\
\hline $4 c$ & $157.34 \mathrm{~s}$ & & $160.43 \mathrm{~s}$ & & & \\
\hline $5 c$ & $115.33 d$ & $6.68(\mathrm{~d}, 8.4)$ & $109.85 d$ & $6.65(\mathrm{~d}, 8.4)$ & & \\
\hline $6 c$ & $129.22 d$ & $6.85(\mathrm{~d}, 8.4)$ & $130.09 \mathrm{~d}$ & $6.98(\mathrm{dd}, 8.4,2.4)$ & & \\
\hline $7 \mathrm{c}$ & $77.10 \mathrm{~d}$ & $4.02(\mathrm{dd}, 4.2,3.0)$ & $131.70 \mathrm{~d}$ & $6.21(\mathrm{~d}, 12.0)$ & & \\
\hline $8 c$ & $65.07 d$ & $2.96(\mathrm{~m})$ & $127.04 \mathrm{~d}$ & $6.05(\mathrm{~d}, 12.0)$ & & \\
\hline $9 c$ & $148.34 \mathrm{~s}$ & & $137.54 \mathrm{~s}$ & & & \\
\hline $10 c$ & $123.66 \mathrm{~s}$ & & $107.71 d$ & $6.03(\mathrm{~d}, 2.4)$ & & \\
\hline $11 \mathrm{c}$ & $154.66 \mathrm{~s}$ & & $159.79 \mathrm{~s}$ & & & \\
\hline $12 \mathrm{c}$ & $102.22 d$ & $6.24(\mathrm{~d}, 1.8)$ & $102.54 \mathrm{~d}$ & $6.17(t, 2.4)$ & & \\
\hline $13 c$ & $158.38 \mathrm{~s}$ & & $159.79 \mathrm{~s}$ & & & \\
\hline $14 \mathrm{c}$ & $106.66 \mathrm{~d}$ & $5.17(\mathrm{~d}, 1.8)$ & $107.71 \mathrm{~d}$ & $6.03(\mathrm{~d}, 2.4)$ & & \\
\hline
\end{tabular}

* Data $\left(\delta_{\mathrm{H}}\right)$ were measured in MeOD for ${ }^{1} \mathrm{H}-\mathrm{NMR}$ at $600 \mathrm{MHz}$ and for ${ }^{13} \mathrm{C}-\mathrm{NMR}$ at $150 \mathrm{MHz}$. The assignments were based on DEPT, ${ }^{1} \mathrm{H}-{ }^{1} \mathrm{H}$ COSY, HSQC, HMBC, and NOESY experiments, respectively. 

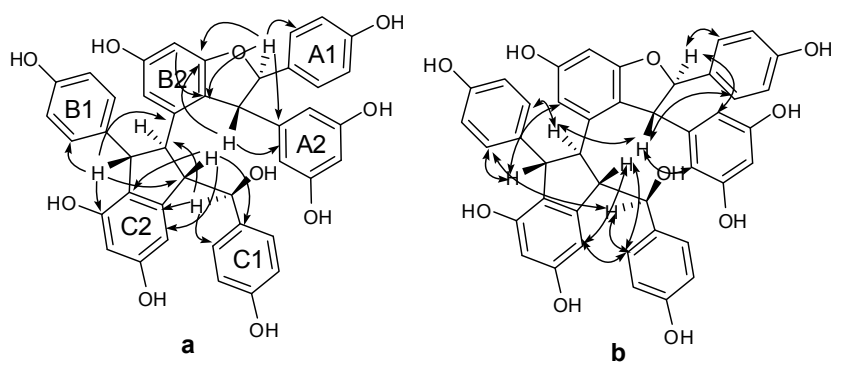

Figure 3. Important HMBC (a) and NOESY (b) interactions of 3.

The stereochemistry of $\mathbf{3}$ was determined by analyzing the NOESY spectrum (Figure S6 and Figure $3 \mathrm{~b}$ ). The interactions among $\mathrm{H}-2(6) \mathrm{b}$ and $\mathrm{H}-7 \mathrm{~b}, \mathrm{H}-8 \mathrm{~b}$ suggested a trans orientation of rings B1 and B2. The NOE interactions among H-7c and H-2(6)c, H-2(6)b suggested a cis orientation of rings $\mathrm{C} 1$ and $\mathrm{B} 1$. The NOE interactions between H-8a and H-2(6)a and between H-7a and H-10(14)a indicated a trans orientation between rings $\mathrm{A} 1$ and $\mathrm{A} 2$. Furthermore, the NOE interactions among $\mathrm{H}-14 \mathrm{c}$ and $\mathrm{H}-2(6) \mathrm{c}, \mathrm{H}-8 \mathrm{c}$ revealed that ring $\mathrm{C} 1$ could be located near ring $\mathrm{C} 2$. The downfield shift of H-14c $(6.68-6.65(\mathrm{~m}, 1 \mathrm{H}))$ and upfield shift of $\mathrm{H}-8 \mathrm{~b}(2.81(\mathrm{~s}, 1 \mathrm{H}))$ in 3 compared with those of davidiol B further substantiated this observation. Therefore, the structure of $\mathbf{3}$ was determined as shown in Figure 1.

Compound 4 was obtained as a light brown amorphous powder. Its corresponding negative HR-ESI-MS (Figure S4) $m / z 679.1973[\mathrm{M}-\mathrm{H}]^{-}$(cacld. for $\mathrm{C}_{42} \mathrm{H}_{31} \mathrm{O}_{9}, 679.1968$ ) showed a molecular formula of $\mathrm{C}_{42} \mathrm{H}_{31} \mathrm{O}_{9}$, which implied that 4 could be a resveratrol trimer. The UV ( $\lambda_{\max }=203.4$ (4.99), 228 (4.69), and $281(4.22) \mathrm{nm})$ and IR $\left(v_{\max }=3335,1604,1516,1487,1449,1004\right.$, and $\left.836 \mathrm{~cm}^{-1}\right)$ spectra (Figures S18 and S19) of 4 displayed the presence of a phenolic oligostilbene containing a cis olefinic bond [21]. The ${ }^{1} \mathrm{H}$ - and ${ }^{13} \mathrm{C}-\mathrm{NMR}$ spectral data (Figures $\mathrm{S} 10$ and S11, Table 1) of 4, along with ${ }^{1} \mathrm{H}-{ }^{1} \mathrm{H}$ COSY, DEPT, HSQC, and HMBC spectra (Figures S12 S14 and S16), revealed resonances attributable to two 4-hydroxyphenyl groups (rings A1 and B1), two 3,5-dihydroxyphenyl groups (rings A2 and C2), a 3,5-dihydroxy-1,2-disubstituted benzene ring (ring B2), and a 4-hydroxy-1,3-disubstituted benzene ring (ring $\mathrm{C} 1$ ). The ${ }^{1} \mathrm{H}-\mathrm{NMR}$ spectral data also suggested the presence of two sets of aliphatic signals at $\delta_{\mathrm{H}}$ of $5.22(1 \mathrm{H}, \mathrm{d}, J=6.1 \mathrm{~Hz}, \mathrm{H}-7 \mathrm{a})$ and $3.85(1 \mathrm{H}, \mathrm{d}, J=6.1 \mathrm{~Hz}, \mathrm{H}-8 \mathrm{a})$. These signals are characteristic of a 2,3-diaryldihydrobenzofuran moiety, except a cis-1,2-disubstituted olefinic bond at $\delta_{\mathrm{H}} 6.21(1 \mathrm{H}, \mathrm{d}, J=12.0 \mathrm{~Hz}, \mathrm{H}-7 \mathrm{c})$ and $6.05(1 \mathrm{H}, \mathrm{d}, J=12.0 \mathrm{~Hz}, \mathrm{H}-8 \mathrm{c})$. Our comparison revealed that the NMR spectroscopic data of 4 were remarkably similar to those of cis-diptoindonesin B reported in the literature [21], which suggested that 4 possessed the same planar structure as cis-diptoindonesin B. In the HMBC spectrum (Figure S14 and Figure 4a) of 4, the significant correlations of H-7a/C-2(6)a, C-9a, and C-11b; H-8a/C-10(14)a, C-1a, and C-9b; H-7b/C-2(6)b, and C-9b; and H-8b/C-1b, C-2c, and $\mathrm{C}-4 \mathrm{c} ; \mathrm{H}-7 \mathrm{c} / \mathrm{C}-5 \mathrm{c} ; \mathrm{H}-8 \mathrm{c} / \mathrm{C}-2(6) \mathrm{c}$, in combination with their shifts, further supported the planar structure of 4 as shown in Figure 1.

The relative stereochemistry of $\mathrm{H}-7 \mathrm{a} / \mathrm{H}-8 \mathrm{a}$ and $\mathrm{H}-7 \mathrm{~b} / \mathrm{H}-8 \mathrm{~b}$ was determined by analyzing the NOESY spectrum of 4 (Figure S15 and Figure 4b). The NOE interactions among H-7a and H-2(6)a, $\mathrm{H}-10(14) \mathrm{a}$ and those among $\mathrm{H}-8 \mathrm{a}$ and $\mathrm{H}-2(6) \mathrm{a}, \mathrm{H}-10(14 \mathrm{a})$ suggested a trans orientation between $\mathrm{H}-7 \mathrm{a}$ and H-8a. Similarly, the NOE interactions between H-8b and H-2(6)b also suggested a trans relationship of $\mathrm{H}-7 \mathrm{~b}$ and H-8b. Despite that 4 exhibited a planar structure similar to that of cis-diptoindonesin B, their difference indicated that 4 could be a stereoisomer of cis-diptoindonesin $\mathrm{B}$. The comparison of the NMR data of 4 with cis-diptoindonesin B demonstrated that H-8a, H-8c, and H-10(14)c and C-8b, C-9b, $\mathrm{C}-8 \mathrm{c}$, and $\mathrm{C}-9 \mathrm{c}$ in 4 were shifted by $\Delta \delta_{\mathrm{H}}$ of $+0.36,-0.24,-0.19$ and $\Delta \delta_{\mathrm{C}}$ of $+3.3,+4.7,-2.5$, and -3.5 $\mathrm{ppm}$, respectively. This evidence demonstrated that the relative configurations of $\mathrm{C}-7 \mathrm{~b}$ and $\mathrm{C}-8 \mathrm{~b}$ in 4 could be $7 \mathrm{~b} R$ and $8 \mathrm{~b} R$ instead of $7 \mathrm{bS}$ and $8 \mathrm{bS}$ in cis-diptoindonesin $\mathrm{B}$, respectively [21]. In contrast to the relative configuration of $\mathrm{rel}-(7 \mathrm{a} S, 8 \mathrm{a} S, 7 \mathrm{bS}$, and $8 \mathrm{bS})$ in cis-diptoindonesin $\mathrm{B}$, the relative configurations of 4 for C-7a, C-8a, C-7b, and C-8b were determined as rel-(7aS, $8 \mathrm{a} S, 7 \mathrm{~b} R$, and $8 \mathrm{~b} R)$, respectively 
(Figure 1). This conjecture was confirmed by the fact that $\mathrm{H}-8 \mathrm{a}$ and $\mathrm{H}-2(6) \mathrm{b}$ were deshielded because of anisotropic effects induced by rings B2 and C1. On the contrary, H-7c, H-8c, and H-10(14)c were shielded due to anisotropic effects elicited by rings B2.
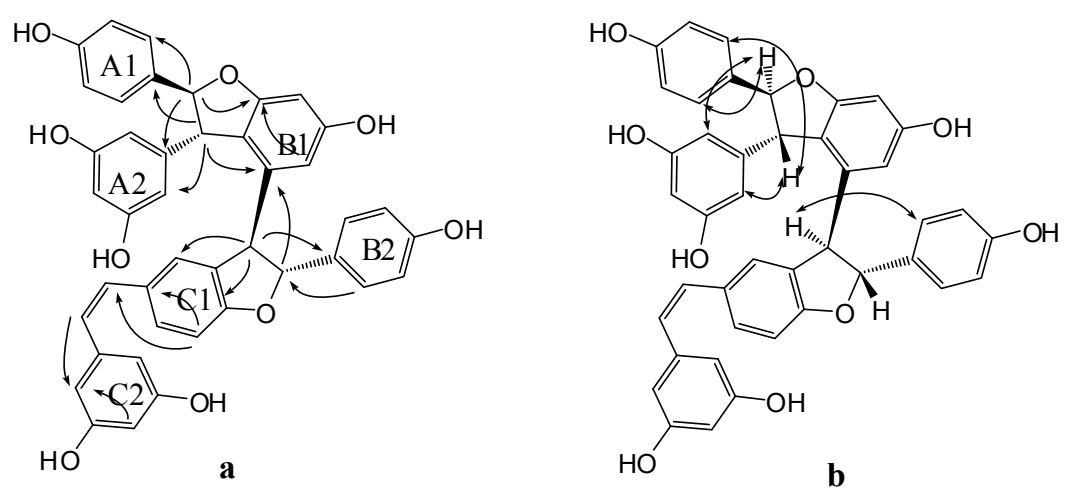

Figure 4. Significant HMBC (a) and NOESY (b) correlations of compound 4.

Compound 5 was obtained as brown amorphous powder. The corresponding positive ion HR-ESI-MS (Figure S27) peak at $m / z 337.1073[\mathrm{M}+\mathrm{H}]^{+}$(cacld. for $\mathrm{C}_{20} \mathrm{H}_{17} \mathrm{O}_{5}, 337.1071$ ) provided the molecular formula of $\mathrm{C}_{20} \mathrm{H}_{16} \mathrm{O}_{5}$. The IR spectrum (Figure S29) displayed the presence of hydroxyls $\left(3337 \mathrm{~cm}^{-1}\right)$ and aromatic rings $\left(1615,1517\right.$, and $\left.1464 \mathrm{~cm}^{-1}\right)$. The ${ }^{1} \mathrm{H}-\mathrm{NMR}$ spectrum (Figure S20, Table 1) showed one A2B2 system at $\delta_{\mathrm{H}}$ of $7.20(2 \mathrm{H}, \mathrm{d}, J=8.5 \mathrm{~Hz}, \mathrm{H}-3(5) \mathrm{a})$ and $6.82(2 \mathrm{H}, \mathrm{d}, J=8.5 \mathrm{~Hz}$, $\mathrm{H}-3(5) \mathrm{a})$, one $\mathrm{AB} 2$ system at $\delta_{\mathrm{H}}$ of $6.25(1 \mathrm{H}, \mathrm{t}, J=2.1 \mathrm{~Hz}, \mathrm{H}-12 \mathrm{a})$ and $6.16(2 \mathrm{H}, \mathrm{d}, J=2.1 \mathrm{~Hz}, \mathrm{H}-10(14) \mathrm{a})$, one $\mathrm{ABX}$ system at $\delta_{\mathrm{H}}$ of $6.47(1 \mathrm{H}, \mathrm{d}, J=2.2 \mathrm{~Hz}, \mathrm{H}-3 \mathrm{~b})$ and $6.67(2 \mathrm{H}, \mathrm{brs}, \mathrm{H}-5 \mathrm{~b}, \mathrm{H}-6 \mathrm{~b})$, and two mutually coupled benzyl methine protons at $\delta_{\mathrm{H}}$ of $5.34(1 \mathrm{H}, \mathrm{d}, J=8.3 \mathrm{~Hz}, \mathrm{H}-7 \mathrm{a})$ and $4.36(1 \mathrm{H}, \mathrm{d}, J=8.3 \mathrm{~Hz}, \mathrm{H}-7 \mathrm{a})$. In addition, the carbon signals at $\delta_{C}$ of 54.66 and 92.53 ppm in ${ }^{13} \mathrm{C}-\mathrm{NMR}$ (Figure S21, Table 1), together with the proton signals at $\delta_{\mathrm{H}}$ of 5.34 and $4.36 \mathrm{ppm}$, suggested the presence of dihydroxybenzofuran ring. Accordingly, $\mathbf{5}$ was identified as a resveratrol derivative with benzofuran skeleton, as shown in Figure 1, which was confirmed by DEPT, HSQC, HMBC, COSY, and UV spectra (Figures S22 S26 and S28). In HMBC spectrum (Figure S24 and Figure 5a), the correlations between H-7a and C-2(6)a, C-9a, C-2b and H-8a and C-10(14)a, C-1a, C-6b suggested that ring A1 could be linked at C-7a, and ring A2 could be linked at C-8a. In NOESY experiment (Figure S25 and Figure 5b), the NOE enhancements between $\mathrm{H}-7 \mathrm{a}$ and $\mathrm{H}-2(6) \mathrm{a} / \mathrm{H}-10(14) \mathrm{a}$ and $\mathrm{H}-8 \mathrm{a}$ and $\mathrm{H}-10(14) \mathrm{a} / \mathrm{H}-2(6)$ a suggested a trans orientation of rings A1 and A2. Therefore, the structure of 5 was determined as shown in Figure 1.
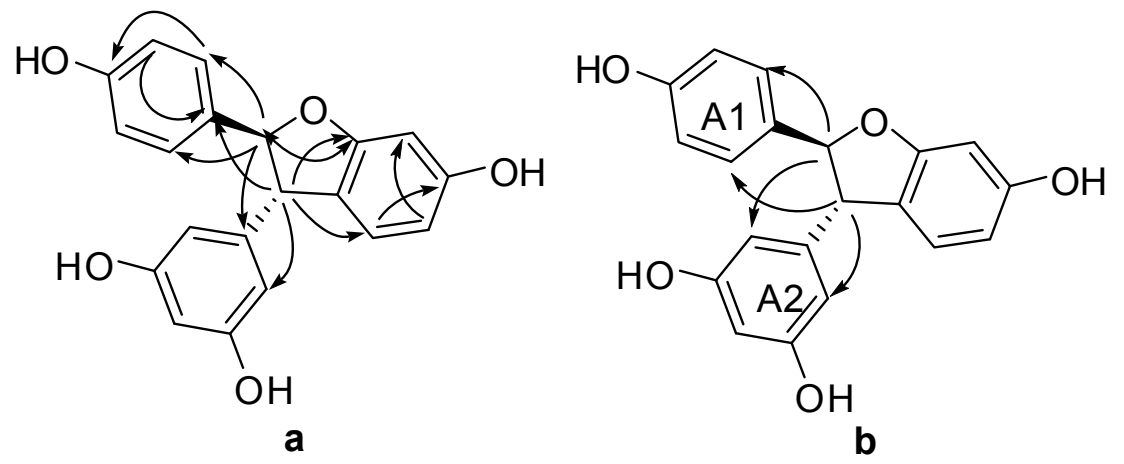

Figure 5. Significant HMBC (a) and NOESY (b) correlations of compound 5.

In addition to these three compounds, two known resveratrol trimers, namely, davidiol B (6) [18] and rel-(7aS,8aS,7bS,8bS)-cis-diptoindonesin B (7) [21], and six known dimers, namely, $( \pm)$-resveratroltrans-dehydrodimer (8) [22,23], ( \pm )-resveratrol-cis-dehydrodimer (9) [23,24], leachianol G (10) [25,26], 
leachianol F (11) [25,26], parthenostilbenin B (12) [20], and ampelopsin B (13) [27,28], were identified by comparing their physical and spectroscopic data with those reported in previous studies. Among them, trimers 6 and 7, which are difficult to obtain by common organic reactions, were obtained for the first time by direct biotransformation from resveratrol.

\subsection{Probable Coupling Reaction Mechanisms}

Considering the obtained results, a mechanism on how different trimeric derivatives formed were proposed. HRP-catalyzed biotransformation is presumed on the basis of radical reaction [13,14,29]. Induced by hydrogen peroxide, resveratrol, and $( \pm)-\varepsilon$-viniferin were dehydrogenated and rearranged to form different radicals (Figure 6). Afterward, these HRP-catalyzed radicals were combined to produce different dimers and trimers. The coupling of one radical $\mathrm{D}$ and one radical $\mathrm{A}$, and subsequent tautomeric rearrangement and intramolecular nucleophilic attack to the intermediate quinone yielded the dihydrofuran trimers 4 and 7 (Figure 7). Consequently, the formation of 3 and $\mathbf{6}$ can be easily explained by the coupling of one radical $\mathrm{D}$ with one radical $\mathrm{B}$ and subsequent addition of a water molecule to the intermediate quinone (Figure 8). Furthermore, 5 may be formed through the oxidation of $( \pm)$ - $\varepsilon$-viniferin by $\mathrm{H}_{2} \mathrm{O}_{2}$ and $\mathrm{HRP}$, but an appropriate account for the reactivity cannot be established with this evidence. In addition, the formation mechanisms of the dimers obtained in this work are the same as those reported in our previous paper [26,30,31].
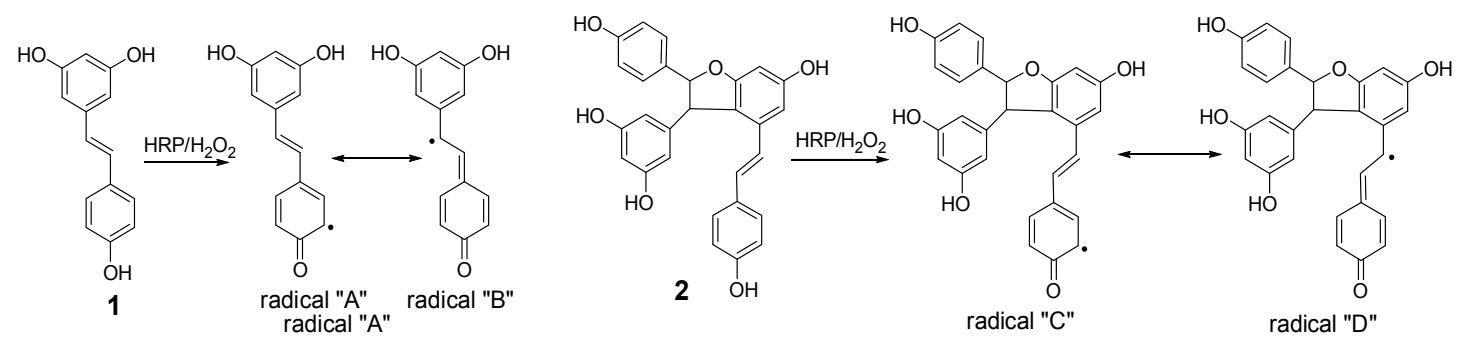

Figure 6. Plausible radical intermediates from $\mathbf{1}$ and $\mathbf{2}$ by horseradish peroxidase and hydrogen peroxide.

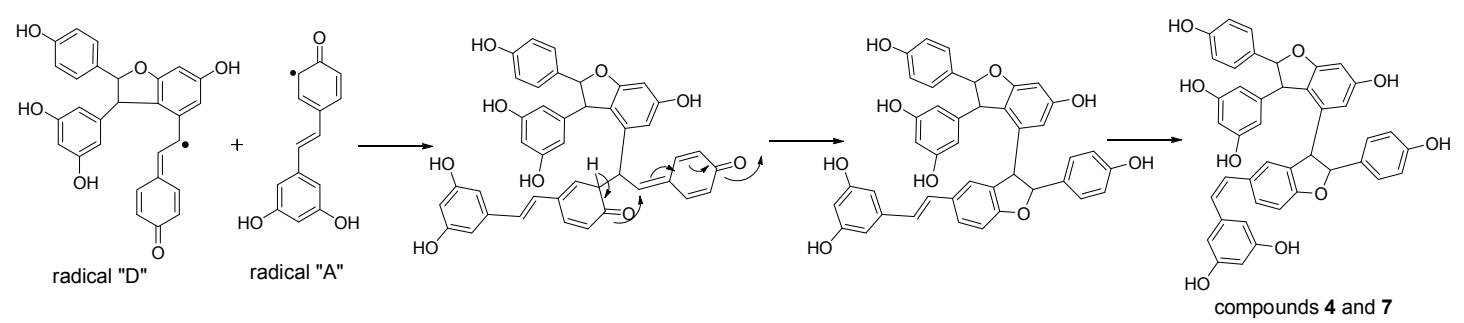

Figure 7. Proposed formation mechanisms for compounds 4 and 7.

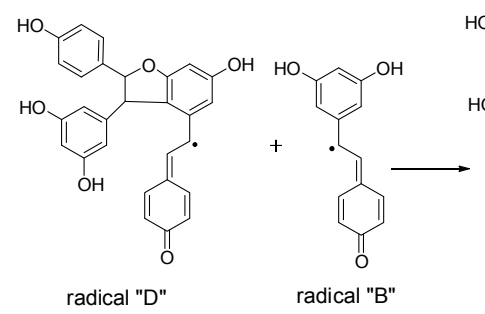

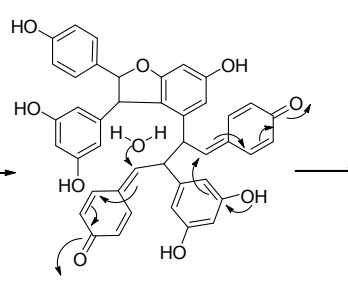

radical "B"

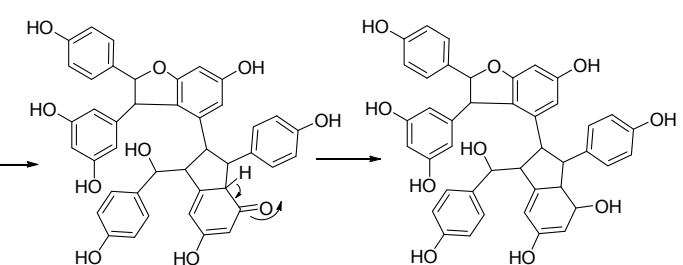

compounds 3 and 6

Figure 8. Proposed formation mechanisms for compounds $\mathbf{3}$ and $\mathbf{6 .}$ 


\section{Materials and Methods}

\subsection{Materials and Instrumentation}

Optical rotations were measured on P2000 polarimeter (JASCO, Tokyo, Japan). UV spectra were obtained on a JASCOP650 spectrometer (JASCO). IR spectra were recorded on a Nicolet 5700 FT-IR microscope instrument (FT-IR microscope transmission, Thermo Electron Corporation, Madison, WI, USA). 1D and 2D NMR spectra were acquired at 500 or $600 \mathrm{MHz}$ for ${ }^{1} \mathrm{H}$ and 125 or $150 \mathrm{MHz}$ for ${ }^{13} \mathrm{C}$, respectively, on Varian INOVA $500 \mathrm{MHz}$, or Bruker AVANCE III HD $600 \mathrm{MHz}$ (Bruker Corporation, Karlsruhe, Germany), in acetone- $d_{6}$ or methanol- $d_{4}$, with solvent peaks as references. ESI-MS and HR-ESI-MS data were measured using an AccuToFCS JMST100CS spectrometer (Agilent Technologies, Ltd., Santa Clara, CA, USA). Column chromatography (CC) was performed with silica gel (200-300 mesh, Qingdao Marine Chemical Inc., Qingdao, China). HPLC separation was performed on an instrument consisting of a Waters 515 pump and a Waters 2487 dual $\lambda$ absorbance detector (Waters Corporation, Milford, MA, USA) with a YMC semi-preparative column $(250 \times 10 \mathrm{~mm}$ i.d.) packed with C18 $(5 \mu \mathrm{M})$. TLC was carried out with glass precoated silica gel GF254 plates (Qingdao Marine Chemical, Inc., Qingdao, China). Spots were visualized under UV light or by spraying with $7 \% \mathrm{H}_{2} \mathrm{SO}_{4}$ in $95 \%$ EtOH followed by heating.

\subsection{Synthesis of Compoud 2}

The solution of $\mathrm{FeCl}_{3} \cdot 6 \mathrm{H}_{2} \mathrm{O}(380 \mathrm{~g}, 1.43 \mathrm{~mol})$ in $\mathrm{H}_{2} \mathrm{O}(100 \mathrm{~mL})$ was added to a solution of 1 $(300 \mathrm{~g}, 1.32 \mathrm{~mol})$ in methanol $(500 \mathrm{~mL})$ under stirring at room temperature, and the mixture was stirred for $60 \mathrm{~h}$ at room temperature. After removing of methanol in vacuo, water was added to the mixture, and the mixture was extracted with EtOAc. Subsequently, the obtained organic layer was washed with brine and water, dried over anhydrous $\mathrm{Na}_{2} \mathrm{SO}_{4}$ for $24 \mathrm{~h}$, then concentrated in vacuo to give a residue, which was further chromatographed on silica gel column with $\mathrm{CHCl}_{3}-\mathrm{MeOH}(15: 1, v / v)$ as eluent to provide unreacted resveratrol $130 \mathrm{~g}$ and product 2 (23 g, yield 13.5\%).

Compound 2: grey amorphous powder. ${ }^{1} \mathrm{H}-\mathrm{NMR}\left(\mathrm{CD}_{3} \mathrm{COCD}_{3}, 500 \mathrm{MHz}\right) \delta: 8.41(\mathrm{OH}), 8.38(\mathrm{OH})$, $8.33(\mathrm{OH}), 8.17(2 \mathrm{H}, 2 \times \mathrm{OH}), 7.20(2 \mathrm{H}, \mathrm{d}, J=9.0 \mathrm{~Hz}, \mathrm{H}-2 \mathrm{a}, 6 \mathrm{a}), 7.16(2 \mathrm{H}, \mathrm{d}, J=8.5 \mathrm{H}, \mathrm{H}-2 \mathrm{~b}, 6 \mathrm{~b})$, $6.90(1 \mathrm{H}, \mathrm{d}, J=16.0 \mathrm{~Hz}, \mathrm{H}-7 \mathrm{~b}), 6.82(2 \mathrm{H}, \mathrm{d}, J=9.0 \mathrm{~Hz}, \mathrm{H}-3 \mathrm{a}, 5 \mathrm{a}), 6.73(2 \mathrm{H}, \mathrm{d}, J=8.5 \mathrm{~Hz}, \mathrm{H}-3 \mathrm{~b}, 5 \mathrm{~b})$, $6.72(2 \mathrm{H}, \mathrm{d}, J=2.0 \mathrm{~Hz}, \mathrm{H}-10 \mathrm{a}, 14 \mathrm{a}), 6.70(1 \mathrm{H}, \mathrm{d}, J=16.0 \mathrm{~Hz}, \mathrm{H}-8 \mathrm{~b}), 6.32(1 \mathrm{H}, \mathrm{d}, J=2.0 \mathrm{~Hz}, \mathrm{H}-12 \mathrm{~b})$, $6.23(2 \mathrm{H}, \mathrm{br} \mathrm{s}, \mathrm{H}-12 \mathrm{a}, 14 \mathrm{~b}), 5.41(1 \mathrm{H}, \mathrm{d}, J=5.5 \mathrm{~Hz}, \mathrm{H}-7 \mathrm{a}), 4.47(1 \mathrm{H}, \mathrm{d}, J=5.5 \mathrm{~Hz}, \mathrm{H}-8 \mathrm{a})$; (+)-ESI $m / z$ : $477[\mathrm{M}+\mathrm{Na}]^{+}$.

\subsection{Treatment of $\mathbf{1}$ and $\mathbf{2}$ with Horseradish Peroxidase/Hydrogen Peroxide}

To a mixed solution of 1 (3000 mg, $13.2 \mathrm{mmol})$ and $2(1500 \mathrm{mg}, 3.3 \mathrm{mmol})$ in acetone $(240 \mathrm{~mL})$, $50 \mathrm{~mL}$ of water was added under stirring at room temperature. After that, a solution of HRP (10.0 mg) in water $(30 \mathrm{~mL})$ was added slowly. The reactant was stirred for $5 \mathrm{~min}, 30 \% \mathrm{H}_{2} \mathrm{O}_{2}(1.4 \mathrm{~mL})$ was then added. The reactant was stirred for another $7 \mathrm{~h}$ at room temperature. Finally, the reaction mixture was suspended in water, and extracted with ethyl acetate. The organic layer was dried on anhydrous $\mathrm{Na}_{2} \mathrm{SO}_{4}$ for $24 \mathrm{~h}$, and concentrated in vacuo to yield a residue.

The residue was subjected to column chromatography over ODS, eluting with a gradient of increasing methanol in water $(15 \sim 100 \%)$ to provide nine fractions (R-I R-IX) on the basis of HPLC analysis. R-VI (2.5 g) was further fractionated via silica gel column chromatography (CC), eluting with $\mathrm{CHCl}_{3}-\mathrm{MeOH}(17: 1, v / v)$ to yield $8(0.493 \mathrm{~g}, 16.5 \%)$ and R-VI-2 R-VI-4. R-VI-3 was then separated by semi-preparative Rp-HPLC (column, Rp-18, $250 \times 10 \mathrm{~mm}, 5 \mu \mathrm{m}$ ) eluted using methanol/water $(56: 44, v / v)$ to afford $9(2 \mathrm{mg}, 0.07 \%) ; 30 \mathrm{mg}$ R-I (total $280 \mathrm{mg}$ ) was separated by semi-preparative Rp-HPLC using a mobile phase of methanol/water (16:84, v/v) to afford 10 (9 mg, 2.7\%) and 11 (4 mg, 1.2\%). R-II (30 mg) was further purified by semi-preparative Rp-HPLC eluted with a mobile phase of $\mathrm{MeOH}-\mathrm{H}_{2} \mathrm{O}(30: 70, v / v)$ to afford 5 (1.7 mg). $300 \mathrm{mg}$ R-III (total amount $600 \mathrm{mg}$ ) was 
resolved by Rp-MPLC with a gradient of increasing $\mathrm{MeOH}(18 \sim 30 \%)$ in water to give R-III-1 R-III-3. Among them, Fraction R-III-2 (34 mg) were subsequently separated by Rp-HPLC with a mobile phase of methanol/water $(40: 60, v / v)$ to afford 6 ( $5 \mathrm{mg}, 0.43 \%)$ and 3 ( $3 \mathrm{mg}, 0.26 \%)$; R-III-1 and R-III-3 were dealt with the same manner to provide $13(13 \mathrm{mg}, 0.87 \%)$, and $12(7 \mathrm{mg}, 0.44 \%)$, respectively. Furthermore, R-VII (600 mg) was subjected to Rp-MPLC eluting with methanol-water $(49: 51, v / v)$ to yield R-VII-1 and R-VII-2; subsequently, R-VII-1 was purified by semi-preparative Rp-HPLC using a mobile phase of methanol-water $(46: 54, v / v)$ to provide $7(2 \mathrm{mg})$; R-VII-2 was dealt with methanol-water $(54: 46, v / v)$ by semi-preparative Rp-HPLC in the same manner to give 4 (6 mg).

Compound 3: Brown amorphous powder. UV (MeOH) $\lambda_{\max }(\log \varepsilon)$ : 203 (5.14), 231.2 (4.66), 283 (3.92) nm; IR (film) $v_{\max }: 3395,3187,2921,2850,1646,1513,1469,1420,1342,1245,1120,1005,834,722$, $648 \mathrm{~cm}^{-1}$; ${ }^{1} \mathrm{H}-\mathrm{NMR}(600 \mathrm{MHz}, \mathrm{MeOD})$ and ${ }^{13} \mathrm{C}-\mathrm{NMR}(150 \mathrm{MHz}, \mathrm{MeOD})$, see Table $1 ;(+)$-ESI $m / z$ : $721.0[\mathrm{M}+\mathrm{Na}]^{+}, 736.9\left[\mathrm{M}+\mathrm{K}^{+} ;(-)\right.$-ESI $m / z: 696.9[\mathrm{M}-\mathrm{H}]^{-}, 732.9[\mathrm{M}+\mathrm{Cl}]^{-} ; \mathrm{HR}-\mathrm{ESI}-\mathrm{MS} \mathrm{m} / z$ : 697.2076, [M - H] $]^{-}$(cacld. for $\mathrm{C}_{42} \mathrm{H}_{33} \mathrm{O}_{10}, 697.2079$ ).

Compound 4: Light brown amorphous powder. UV (MeOH) $\lambda_{\max }(\log \varepsilon): 203.4$ (4.99), 228 (4.69), 281 (4.22) nm; IR (film) $v_{\max }$ : 3335, 2924, 2852, 1604, 1516, 1487, 1449, 1349, 1241, 1169, 1004, 836, $694 \mathrm{~cm}^{-1}$; ${ }^{1} \mathrm{H}-\mathrm{NMR}(600 \mathrm{MHz}, \mathrm{MeOD})$ and ${ }^{13} \mathrm{C}-\mathrm{NMR}(150 \mathrm{MHz}, \mathrm{MeOD})$, see Table $1 ;(+)$-ESI $m / z$ : $703.3[\mathrm{M}+\mathrm{Na}]^{+} ;(-)$-ESI $m / z: 678.9[\mathrm{M}-\mathrm{H}]^{-}, 715.8[\mathrm{M}+\mathrm{Cl}]^{-} ;$HR-ESI-MS $m / z: 679.1973,[\mathrm{M}-\mathrm{H}]^{-}$ (cacld. for $\mathrm{C}_{42} \mathrm{H}_{31} \mathrm{O}_{9}, 679.1968$ ).

Compound 5: Brown amorphous powder. UV (MeOH) $\lambda_{\max }(\log \varepsilon)$ : 203.4 (4.73), 229.8 (4.29), 283 (3.70) nm; IR (film) $v_{\max }$ : 3337, 2921, 2852, 1615, 1517, 1488, 1464, 1351, 1235, 1198, 1157, 1105, $1000,836,778,746,691 \mathrm{~cm}^{-1} ;{ }^{1} \mathrm{H}-\mathrm{NMR}\left(600 \mathrm{MHz}\right.$, acetone- $\left.d_{6}\right)$ and ${ }^{13} \mathrm{C}-\mathrm{NMR}\left(150 \mathrm{MHz}\right.$, acetone- $\left.d_{6}\right)$, see Table 1; HR-ESI-MS $m / z: 337.1073[\mathrm{M}+\mathrm{H}]^{+}$(cacld. for $\mathrm{C}_{20} \mathrm{H}_{17} \mathrm{O}_{5}, 337.1071$ ).

Davidiol B (6): Brown amorphous powder. ${ }^{1} \mathrm{H}-\mathrm{NMR}\left(600 \mathrm{MHz}\right.$, acetone- $\left.d_{6}\right), \delta: 7.00(2 \mathrm{H}, \mathrm{d}, J=8.5 \mathrm{~Hz}$, H-2(6)a), 6.87 (2H, d, J = 8.5 tHz, H-3(5)a), 6.68-6.65 (1H, m, H-14c), 6.53 (2H, d, J = 8.6 Hz, H-3(5)b), $6.45(2 \mathrm{H}, \mathrm{d}, J=8.5 \mathrm{~Hz}, \mathrm{H}-3(5) \mathrm{c}), 6.38(1 \mathrm{H}, \mathrm{d}, J=2.1 \mathrm{~Hz}, \mathrm{H}-12 \mathrm{c}), 6.35(2 \mathrm{H}, \mathrm{d}, J=8.4 \mathrm{~Hz}, \mathrm{H}-2(6) \mathrm{c})$, $6.31(1 \mathrm{H}, \mathrm{t}, J=2.2 \mathrm{~Hz}, \mathrm{H}-12 \mathrm{a}), 6.16(1 \mathrm{H}, \mathrm{d}, J=2.1 \mathrm{~Hz}, \mathrm{H}-12 \mathrm{~b}), 6.13(2 \mathrm{H}, \mathrm{d}, J=8.4 \mathrm{~Hz}, \mathrm{H}-2(6) \mathrm{b}), 5.99(1 \mathrm{H}$, d, $J=2.1 \mathrm{~Hz}, \mathrm{H}-14 \mathrm{~b}), 5.91(2 \mathrm{H}, \mathrm{d}, J=2.0 \mathrm{~Hz}, \mathrm{H}-10(14) \mathrm{a}), 5.05(1 \mathrm{H}, \mathrm{d}, J=2.3 \mathrm{~Hz}, \mathrm{H}-7 \mathrm{a}), 4.10(1 \mathrm{H}, \mathrm{s}$, H-7b), 3.95 (1H, d, J = 10.1 Hz, H-7c), $3.11(1 \mathrm{H}, \mathrm{d}, J=2.4 \mathrm{~Hz}, \mathrm{H}-8 \mathrm{a}), 2.90$ (1H, d, J = $10.1 \mathrm{~Hz}, \mathrm{H}-8 \mathrm{c}), 2.81$ $(1 \mathrm{H}, \mathrm{s}, \mathrm{H}-8 \mathrm{~b}) .{ }^{13} \mathrm{C}-\mathrm{NMR}\left(150 \mathrm{MHz}\right.$, acetone- $\left.d_{6}\right), \delta: 161.74 \mathrm{~s}(\mathrm{C}-11 \mathrm{~b}), 159.94 \mathrm{~s}$ (C-11(13)a), 159.83s (C-13b), 158.71s (C-13c), 157.90s (C-4a), 157.48s (C-4c), 155.84s (C-4b), 154.98s (11c), 150.15s (C-9c), 148.81s (C-9a), 148.01s (C-9b), 136.55s (C-1b), 136.18s (C-1c), 134.35s (C-1a), 129.72d (C-2(6)b), 128.66d (C-2(6)c), 127.57d (C-2(6)a), 122.69s (C-10c), 118.50s (C-10b), 116.41d (C-3(5)c), 116.02d (C-3(5)a), 115.18d (C-3(5)b), 107.41d (C-14c), 106.90d (C-10(14)a), 104.52d (C-14b), 102.11d (C-12c), 101.70d (C-12a), 63.97d (C-8c), 54.57d (C-8b), 54.46d (C-8a), 53.24d (C-7b). (+)-ESI $m / z: 721.0[\mathrm{M}+\mathrm{Na}]^{+}, 736.9[\mathrm{M}+\mathrm{K}]^{+} ;(-)-\mathrm{ESI} m / z$ : $696.9[\mathrm{M}-\mathrm{H}]^{-}, 732.9[\mathrm{M}+\mathrm{Cl}]^{-}$.

cis-Diptoindonesin $B(7)$ : Brown amorphous powder. ${ }^{1} \mathrm{H}-\mathrm{NMR}\left(600 \mathrm{MHz}\right.$, methanol- $\left.d_{4}\right), \delta: 7.09(1 \mathrm{H}, \mathrm{d}$, $J=8.6 \mathrm{~Hz}, \mathrm{H}-6 \mathrm{c}), 6.99(2 \mathrm{H}, \mathrm{d}, J=8.6 \mathrm{~Hz}, \mathrm{H}-2(6) \mathrm{b}(, 6.92(2 \mathrm{H}, \mathrm{d}, J=8.5 \mathrm{~Hz}, \mathrm{H}-2(6) \mathrm{a}), 6.75(2 \mathrm{H}, \mathrm{d}$, $J=8.6 \mathrm{~Hz}, \mathrm{H}-3(5) \mathrm{a}), 6.68(2 \mathrm{H}, \mathrm{d}, J=8.5 \mathrm{~Hz}, \mathrm{H}-3(5) \mathrm{b}), 6.63(1 \mathrm{H}, \mathrm{brs}, \mathrm{H}-2 \mathrm{c}), 6.60(1 \mathrm{H}, \mathrm{d}, J=8.3 \mathrm{~Hz}, \mathrm{H}-5 \mathrm{c})$, $6.37(1 \mathrm{H}, \mathrm{d}, J=12.2 \mathrm{~Hz}, \mathrm{H}-7 \mathrm{c}), 6.31(1 \mathrm{H}, \mathrm{d}, J=12.2 \mathrm{~Hz}, \mathrm{H}-8 \mathrm{c}), 6.25(1 \mathrm{H}, \mathrm{d}, J=2.1 \mathrm{~Hz}, \mathrm{H}-12 \mathrm{~b}), 6.22(2 \mathrm{H}, \mathrm{d}$, $J=2.2 \mathrm{~Hz}, \mathrm{H}-10(14) \mathrm{c}), 6.19(1 \mathrm{H}, \mathrm{d}, J=2.1 \mathrm{~Hz}, \mathrm{H}-14 \mathrm{~b}), 6.12(1 \mathrm{H}, \mathrm{t}, J=2.2 \mathrm{~Hz}, \mathrm{H}-12 \mathrm{c}), 6.10(1 \mathrm{H}, \mathrm{t}$, $J=2.2 \mathrm{~Hz}, \mathrm{H}-12 \mathrm{a}), 5.85(2 \mathrm{H}, \mathrm{d}, J=2.2 \mathrm{~Hz}, \mathrm{H}-10(14) \mathrm{a}), 5.15(1 \mathrm{H}, \mathrm{d}, J=10.0 \mathrm{~Hz}, \mathrm{H}-7 \mathrm{~b}), 5.14(1 \mathrm{H}, \mathrm{d}$, $J=5.2 \mathrm{~Hz}, \mathrm{H}-7 \mathrm{a}), 4.29(1 \mathrm{H}, \mathrm{d}, J=10.0 \mathrm{~Hz}, \mathrm{H}-8 \mathrm{~b}), 3.49$ (1H, d, $J=5.2 \mathrm{~Hz}, \mathrm{H}-8 \mathrm{a}) .{ }^{13} \mathrm{C}-\mathrm{NMR}(150 \mathrm{MHz}$, methanol- $\left.d_{4}\right), \delta: 162.61 \mathrm{~s}(\mathrm{C}-11 \mathrm{~b}), 160.55 \mathrm{~s}$ (C-4c), 160.25s (C-13b), 159.86s (C-11(13)a), 159.12s (C-11(13)c), 158.81s (C-4b), 158.41s (C-4a), 147.58s (C-9a), 140.93s (C-9c), 140.29s (C-9b), 133.87s (C-1a), 131.92s (C-1b), 131.73s (C-1c), 131.12s (C-3c), 130.32d (C-6c), 129.53d (C-8c), 128.94d (C-2(6)b), 128.17d (C-2(6)a), 127.23d (C-2c), 122.03s (C-10b), 116.36d (C-3(5)b), 116.28d (C-3(5)a), 109.68d (C-5c), 108.53d (C-10(14)c), 108.13d (C-14b), 107.09d (C-10(14)a), 102.56d (C-12c), 102.18d (C-12a), 96.83d (C-12b), 94.99d (C-7b), 
94.55d (C-7a), 56.84d (C-8a), 55.52d (C-8b). (+)-ESI-MS m/z: $681.0[\mathrm{M}+\mathrm{H}]^{+}, 703.0[\mathrm{M}+\mathrm{Na}]^{+}$; (-)-ESI $m / z: 678.9[\mathrm{M}-\mathrm{H}]^{-}, 714.9[\mathrm{M}+\mathrm{Cl}]^{-}$.

Ampelopsin B (13): Brown amorphous powder. ${ }^{1} \mathrm{H}-\mathrm{NMR}\left(500 \mathrm{MHz}\right.$, methanol- $\left.d_{4}\right), \delta: 7.02(2 \mathrm{H}, \mathrm{d}$, $J=8.6 \mathrm{~Hz}, \mathrm{H}-2(6) \mathrm{b}), 6.89(2 \mathrm{H}, \mathrm{d}, J=7.9 \mathrm{~Hz}, \mathrm{H}-2(6) \mathrm{a}), 6.69(2 \mathrm{H}, \mathrm{d}, J=8.6 \mathrm{~Hz}, \mathrm{H}-3(5) \mathrm{b}), 6.60(2 \mathrm{H}, \mathrm{d}$, $J=8.6 \mathrm{~Hz}, \mathrm{H}-3(5) \mathrm{a}), 6.30(1 \mathrm{H}, \mathrm{d}, J=2.2 \mathrm{~Hz}, \mathrm{H}-12 \mathrm{~b}), 6.27(1 \mathrm{H}, \mathrm{d}, J=1.9 \mathrm{~Hz}, \mathrm{H}-14 \mathrm{a}), 6.09(1 \mathrm{H}, \mathrm{d}, J=1.8 \mathrm{~Hz}$, $\mathrm{H}-14 \mathrm{~b}), 6.01(1 \mathrm{H}, \mathrm{d}, J=2.0 \mathrm{~Hz}, \mathrm{H}-12 \mathrm{a}), 5.65(1 \mathrm{H}, \mathrm{d}, J=11.4 \mathrm{~Hz}, \mathrm{H}-7 \mathrm{~b}), 5.14(1 \mathrm{H}, \mathrm{t}, J=3.8 \mathrm{~Hz}, \mathrm{H}-7 \mathrm{a})$, $4.05(1 \mathrm{H}, \mathrm{d}, J=11.4 \mathrm{~Hz}, \mathrm{H}-8 \mathrm{~b}), 3.53(1 \mathrm{H}, \mathrm{dd}, J=17.4,4.1 \mathrm{~Hz}, \mathrm{H}-8 \mathrm{a} \alpha), 3.17(1 \mathrm{H}, \mathrm{brd}, J=17.4 \mathrm{~Hz}, \mathrm{H}-8 \mathrm{a} \beta)$. $(+)$-ESI $m / z: 455.0[\mathrm{M}+\mathrm{H}]^{+}, 477.0[\mathrm{M}+\mathrm{Na}]^{+} ;(-)$-ESI $m / z: 453.0[\mathrm{M}-\mathrm{H}]^{-}, 489.0\left[\mathrm{M}+\mathrm{Cl}^{-}\right.$.

\section{Conclusions}

The HRP-catalyzed biotransformation of $\mathbf{1}$ and $\mathbf{2}$ produced various resveratrol stilbene oligomers, including dimers, trimers, and tetramers. In this reaction mixture, four resveratrol trimers $(\mathbf{3}, \mathbf{4}, \mathbf{6}$, and $\mathbf{7})$, one new resveratrol derivative (5) with a dihydrofuran skeleton, and six dimers (8-13) were isolated and identified. Among these compounds, 3 and 4 were newly identified in our study. The raceme nature of the dimers was indicated by the zero values of their optical rotations, and this finding suggested that a radical mechanism was involved in HRP-catalyzed biotransformation. Our study favored the enzymatic biotransformation of stilbenes by HRP as a prominent method to produce oligomeric stilbenes for research activity. Considering that these new compounds may occur naturally as minor constituents, we observed that our reference data provided a basis for the detection of the presence of these stilbene oligomers in future investigations. Oligostilbenes were reported to show various activities [1,2]. Therefore, these products should be further examined, and results will be reported in our future research.

Supplementary Materials: The following are available online. Figures S1 S9: ${ }^{1} \mathrm{H}-\mathrm{NMR},{ }^{13} \mathrm{C}-\mathrm{NMR}$, DEPT, HSQC, HMBC, NOESY, HRESIMS, UV, and IR spectra in $\mathrm{CD}_{3} \mathrm{COCD}_{3}$ of 3. Figures S10 S19: ${ }^{1} \mathrm{H}-\mathrm{NMR},{ }^{13} \mathrm{C}-\mathrm{NMR}, \mathrm{DEPT}$, HSQC, HMBC, NOESY, COSY, HRESIMS, UV, and IR spectra in $\mathrm{CD}_{3} \mathrm{COCD}_{3}$ of 4. Figures S20 S29: ${ }^{1} \mathrm{H}-\mathrm{NMR}$, ${ }^{13} \mathrm{C}-\mathrm{NMR}$, DEPT, HSQC, HMBC, NOESY, COSY, HRESIMS, UV, and IR spectra in $\mathrm{CD}_{3} \mathrm{COCD}_{3}$ of 5 . Figure S30: HPLC chromatogram of biotransformation products of $\mathbf{1}$ and $\mathbf{2}$.

Acknowledgments: This study was conducted with grants from the Key Project of National Natural Science Funds of China (No. 81630094) and the CAMS Innovation Fund for Medical Sciences (No. 2016-I2M-2-002). We are grateful to the department of Instrumental Analysis, Institute of Materia Medica, Chinese Academy of Medical Sciences, and Peking Union Medical College for measuring the IR, NMR, and MS spectra.

Author Contributions: C.-S.Y. and J.-Q.Z. conceived, designed the experiments and wrote the paper; J.-Q.Z., Y.-L.K. and B.-H.T. performed the experiments; C.-S.Y. and G.-P.L. analyzed the data. All authors read and approved the final manuscript.

Conflicts of Interest: The authors declare no conflict of interest.

\section{References}

1. Yao, C.S.; Wang, X.F. Naturally active oligostilbenes. J. Asian Nat. Prod. Res. 2016, 18, 376-407.

2. Lin, M.; Yao, C.S. Natural oligostilbenes. Stud. Nat. Prod. Chem. 2006, 33, 601-644.

3. Shen, T.; Wang, X.N.; Lou, H.X. Natural stilbenes: An overview. Nat. Prod. Rep. 2009, 26, 916-935. [CrossRef] [PubMed]

4. Lindgren, A.E.G.; Oberg, C.T.; Hillgren, J.M.; Elofsson, M. Total synthesis of the resveratrol oligomers

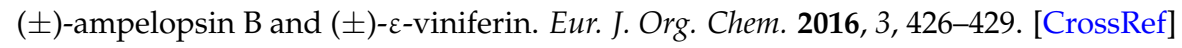

5. Snyder, S.A.; Gollner, A.; Chiriac, M. Regioselective reactions for programmable resveratrol oligomer synthesis. Nature 2011, 474, 461-466. [CrossRef] [PubMed]

6. Snyder, S.A.; Breazzano, S.P.; Ross, A.G.; Lin, Y.; Zografos, A.L. Total synthesis of diverse carbogenic complexity within the resveratrol class from a common building block. J. Am. Chem. Soc. 2009, 131, 1753-1765. [CrossRef] [PubMed] 
7. Kim, I.; Choi, J. A versatile approach to oligostilbenoid natural products-synthesis of permethylated analogues of viniferifuran, malibatol A, and shoreaphenol. Org. Biomol. Chem. 2009, 7, 2788-2795. [CrossRef] [PubMed]

8. Jeffrey, J.L.; Sarpong, R. Concise synthesis of pauciflorol F using a larock annulation. Org. Lett. 2009, 11, 5450-5453. [CrossRef] [PubMed]

9. Snyder, S.A.; Zografos, A.L.; Lin, Y. Total synthesis of resveratrol-based natural products: A chemoselective solution. Angew. Chem. Int. Ed. 2007, 46, 8186-8191. [CrossRef] [PubMed]

10. Li, W.; Li, H.; Li, Y.; Hou, Z. Total synthesis of ( \pm )-quadrangularin A. Angew. Chem. Int. Ed. 2006, 45, 7609-7611. [CrossRef] [PubMed]

11. Li, W.L.; Zang, P.; Li, H.F.; Yang, S. Biomimetic synthesis of oligostilbenes. Prog. Chem. 2012, 24, 545-555.

12. Langcake, P.; Pryce, R.J. Oxidative dimerization of 4-hydroxystilbenes in vitro: Production of a grapevine phytoalexin mimic. J. Chem. Soc. Chem. Commun. 1977, 7, 208-210. [CrossRef]

13. Wan, X.; Wang, X.B.; Yang, M.H.; Wang, J.S.; Kong, L.Y. Dimerization of peceatannol by Momordica charantia peroxidase and $\alpha$-glucosidase inhibitory activity of the biotransformation products. Bioorg. Med. Chem. 2011, 19, 5085-5092. [CrossRef] [PubMed]

14. Ponzoni, C.; Beneventi, E.; Cramarossa, M.R.; Raimondi, S.; Trevisi, G.; Pagnoni, U.M.; Riva, S.; Forti, L. Laccase-catalyzed dimerization of hydroxystilbenes. Adv. Synth. Catal. 2007, 349, 1497-1506. [CrossRef]

15. He, Y.H.; Takaya, Y.; Terashima, K.; Niwa, M. Determination of absolute structure of (+)-davidiol A. Heterocycles 2006, 68, 93-100. [CrossRef]

16. Wilkens, A.; Paulsen, J.; Wray, V.; Winterhalter, P. Structures of two novel trimeric stilbenes obtained by horseradish peroxidase catalyzed by biotransformtion of trans-resveratrol and (-)-e-viniferin. J. Agric. Food Chem. 2010, 58, 6754-6761. [CrossRef] [PubMed]

17. Yao, C.S.; Lin, M.; Wang, Y.H. Synthesis of the active stilbenoids by photooxidation reaction of trans- $\varepsilon$-viniferin. Chin. J. Chem. 2004, 22, 1350-1355. [CrossRef]

18. Tanaka, T.; Ito, T.; Iinuma, M.; Ohyama, M.; Ichise, M.; Tateishi, Y. Stiblbene oligomers in roots of Sophora davidii. Phytochemistry 2000, 53, 1009-1014. [CrossRef]

19. Ito, T.; Tanaka, T.; Iinuma, M.; Iliya, I.; Nakaya, K.; Ali, Z.; Takahashi, Y.; Sawa, R.; Shirataki, Y.; Murata, J.; et al. New resveratrol oligomers in the stem bark of Vatica pauciflora. Tetrahedron 2003, 59, 5347-5363. [CrossRef]

20. Kim, H.J.; Saleem, M.; Seo, S.H.; Jin, C.; Lee, Y.S. Two new antioxidant stilbene dimers, parthenostilbenins A and B from Parthenocissus tricuspidata. Planta Med. 2005, 71, 973-976. [CrossRef] [PubMed]

21. Syah, Y.M.; Aminah, N.S.; Hakim, E.H.; Aimi, N.; Kitajima, M.; Takayama, H.; Achmad, S.A. Two oligostilbenes, cis and trans-diptoindonein B, from Dryobalanops oblongifolia. Phytochemistry 2003, 63, 913-917. [CrossRef]

22. Roger, P.; Camille, P.; Junlien, B.J.; Raffaele, T.; Kartia, G.; Oliver, V. $\delta$-viniferin, a resveratrol dehydromer: One of the major stilbenes synthesized by stressed grapevine leaves. J. Agric. Food Chem. 2003, 51, 5488-5492.

23. Pilar, R.B.; Lorena, M.C.; Jose, M.L.; Francisco, G.C. Kinetic mechanism and product characterization of the enzymatic peroxidation of pterostilbene as model of the detoxification process of stilbene-type phytoalexins. Phytochemistry 2011, 72, 100-108.

24. Hirano, Y.; Kondo, R.; Skai, K. 5 alpha-reductase inhibitory compounds produced by polymerization of resveratrol with horseradish peroxidase. J. Wood Sci. 2002, 48, 64-68. [CrossRef]

25. Ohyama, M.; Tanaka, T.; Iinuma, M. Five resveratrol oligomers from Roots of Sophara leachiana. Phytochemistry 1995, 38, 733-740. [CrossRef]

26. Xie, J.S.; Wen, J.; Wang, X.F.; Zhang, J.Q.; Zhang, J.F.; Kang, Y.L.; Hui, Y.W.; Zheng, W.S.; Yao, C.S. Potassium hexacyanoferrate (III)-catalyzed dimerization of hydroxystilbene: Biomimetic synthesis of indane stilbene dimers. Molecules 2015, 20, 22662-22673. [CrossRef] [PubMed]

27. Takaya, Y.; Yan, K.X.; Terashima, K.; Ito, J.; Niwa, M. Chemical determination of the absolute structures of resveratrol dimers, ampelopsin A, B. C, D and F. Tetrahedron 2002, 58, 7259-7265. [CrossRef]

28. Keckeis, K.; Sarker, S.D.; Dinan, L. Resveratrol-type oligostilbenes from Iris clarkei antagonize 20-hydroxyecdysone action in the Drosophila melanogaster $\mathrm{B}_{\mathrm{II}}$ cell line. Cell. Mol Life Sci. 2000, 57, 333-336. [CrossRef] [PubMed]

29. Takaya, Y.; Yan, K.X.; Terashima, K.; He, Y.H.; Niwa, M. Biogenetic reactions on stilbene tetramers from Vitaceaeous plants. Tetrahedron 2002, 58, 9265-9271. [CrossRef] 
30. Zhang, Y.; Wang, X.F.; Lin, M.B.; Hou, Q.; Yao, C.S.; Shi, J.G. Preparation of active resveratrol dimeric derivatives by oxidative coupling reaction using AgOAc as oxidant. Chin. J. Org. Chem. 2014, 34, 886-892. [CrossRef]

31. Wang, X.F.; Zhang, Y.; Lin, M.B.; Hou, Q.; Yao, C.S.; Shi, J.G. Biomimetic synthesis of active isorhapontigenin dimers. J. Asian Nat. Prod. Res. 2014, 16, 511-521. [CrossRef] [PubMed]

Sample Availability: Samples of the compounds are not available from the authors.

(C) 2017 by the authors. Licensee MDPI, Basel, Switzerland. This article is an open access article distributed under the terms and conditions of the Creative Commons Attribution (CC BY) license (http:/ / creativecommons.org/licenses/by/4.0/). 